\title{
Canopy Foraging by Two Tropical Honeybees: Bee Height Fidelity and Tree Genetic Neighborhoods
}

\author{
David W. ROUBIK Smithsonian Tropical Research Institute, Apartado 2072, Balboa, Ancon, \\ Republic of Panama (mailing address: Unit 0948, APO AA 34002-0948 USA) \\ Tamiji INOUE Center for Ecological Research, Kyoto University, Shimosakamoto 4, Otsu 520-01, \\ Japan \\ Abang Abdul HAMID Forest Research Branch, Forest Department Sarawak, 93660 Kuching, \\ Sarawak, Malaysia
}

\begin{abstract}
Honeybees trained to scented sugar solution feeders were monitored along $220 \mathrm{~m}$ of canopy walkways and three 50-65 m tree towers using a canopy access system (LHS) in Lambir Hills, Sarawak to study pollination and bee foraging patterns. Feeder presentation was manipulated and included ground level stations to evoke variation in bee search behavior. Apis koschevnikovi (Ak) and Apis dorsata $(A d)$ discovered feeders rapidly and moved $220 \mathrm{~m}$ between tree towers in as little as $6 \mathrm{~min}$, recruiting 2-4 thousand bees in response to $1 \mathrm{~L}$ artificial nectar. Experienced bees discovered new feeders in less than 5 min within LHS. Height fidelity was $70 \%$ within trees and $55 \%$ between trees for $A k$, and $60 \%$ for each among $A d$. Travel between trees tended downward for $A d$ but upward for $A k$, with no vertical directional preference detected within trees. Increased resource patchiness augmented bee vagility, but not appreciably between trees. Bees visited feeders between tree tops and ground level, some traveling at least $640 \mathrm{~m}$. Thus, genetic neighborhood size of plants they pollinate exceeds $0.3 \mathrm{~km}^{2}$.
\end{abstract}

Key Words: honeybee / Apis / foraging / canopy

Honeybees are among the most frequent visitors of flowering trees in southeast Asian forests (Appanah, 1979, 1981, 1987, Inoue et al., 1990, 1993, Salmah et al., 1990). While African honeybees and some native neotropical bees forage both in the canopy and understory (Roubik, 1993a, Nieh and Roubik, in press), others seem restricted primarily to lower strata, and canopy specialists are unknown (Roubik, 1993a, Nagamitsu and Inoue, 1994). Nonetheless, general searching behavior and ultimately the movement patterns of pollinator's foraging in the canopy remain unassessed variables (but see Kevan, 1990, Bawa et al., 1985, review by Roubik, 1989). Recent electrophoretic work (Murawski, 1995) shows that gene flow usually occurs between adjacent trees, as predicted by Frankie et al. (1976) but many details of pollinator behavior and patterns of gene flow have not been studied.

In 1993 we completed a canopy access system in the mixed dipterocarp forest of Lambir Hills National Park, Sarawak, to investigate pollination biology (Inoue and Hamid, 1994). This paper reports the inter-tree movement, site constancy, stratum selection behavior and height fidelity of two common honeybees in southeast Asian forests, Apis koschevnikovi and A. dorsata, trained to artificial nectar feeders distributed within forest canopy. Their performance as social bees recruiting many foragers is used to derive a general model of pollinator behavior using empirical data covering most of the tropical forest canopy. 


\section{METHODS AND MATERIALS}

The canopy access system in Lambir Hills National Park (LHS) consists of a $220 \mathrm{~m}$ of walkways connecting eight trees to two wooden tree towers, built alongside the arboreal endpoints of the system. Tower 2 (T2) is attached to an individual $50 \mathrm{~m}$ Dipterocarpus pachyphyllus and Tower 1 (T1) is constructed around a $70 \mathrm{~m}$ Dryobalanops lanceolata. Tower 3 (T3), consisting of four platforms connected by aluminum ladders, is located on an individual Dryobalanops aromatica of $55 \mathrm{~m}$ height, $70 \mathrm{~m}$ SE of T1. Studies were made during April, 1993 and March-April, 1995 using a range of positions accessible by the combined LHS trees, towers and walkways, and also positions near ground level.

Sugar or honey solutions were used to attract foraging honeybees, marked with paint of different colors according to the feeding station where they first arrived. Observations were made for 9 days in 1993 and 14 days in 1995. Foraging performance was analyzed to estimate foraging range and, consequently, the genetic neighborhood of trees pollinated by the honeybees. Further, relatively few competing trees or shrubs were in flower, allowing us to quantify the following aspects of bee foraging behavior and to construct falsifiable hypotheses:

1) Forage discovery rate and colony forager recruitment dynamics

2) Forager population size

3) Intertree movement patterns:

a) rate and speed of movement between tree towers

b) degree of height fidelity (proportion of re-sighted marked individuals returning to the original level where marked)

c) proportion of marked individuals arriving at lower or higher forage sites

d) factors promoting inter-tree movement as a function of: i) distance between forage sites; ii) height of forage sites; iii) temporal and spatial pattern of forage presentation

4) Intratree movement patterns: degree of height fidelity

Weather conditions were usually still and humid during the morning, with occasional thunderstorms in early afternoon terminating our studies. Observations usually commenced before 0700 and ended by mid afternoon. Air temperatures ranged from $29^{\circ} \mathrm{C}$ to $33^{\circ} \mathrm{C}$ during the studies, with a maximum of $40^{\circ} \mathrm{C}$ recorded in full sunlight at $45 \mathrm{~m}$ on T2.

Sugar bait presentation incorporated hand-held spray bottles and saturated sponges in plastic containers. Sugar solutions were made by diluting honey with water in a 1:1 mixture, yielding a solution $40 \%$ sugar by weight, or by mixing table sugar with water, 2:1 by volume, yielding $50 \%$ sugar solutions by weight (measured with a refractometer). Both solutions were flavored with anise extract by 3-5 drops per liter. Used primarily to initiate baiting studies, the hand-held sprayer and honey water were expected to enhance olfactory detection by foraging bees. Several ml of solution were sprayed in a fine mist directly on leaves (see Roubik, 1980). After bees arrived at the honey-water, the sprayer was used to apply bait to light blue or yellow sponge feeders. On following days, sugar water was poured directly onto sponges of $3 \mathrm{~cm}$ thickness in plastic containers, and replenished periodically with the sprayer or by pouring, with minimal dispensation of sprayed mist.

A total of 1 liter solution was used for the feeding studies each day. Bait presentation was terminated when foragers had removed the 1 liter of solution, which was dispensed periodically during counts of the foraging bees. In studies of 1993, three to seven individual feeders were used at one time, and during 1995, up to eight feeders were presented simultaneously. Feeder positions and presentation schedules are summarized in Table 1. On walkways, feeders were 
Table 1. Feeder presentation and marking schemes of honeybees, Apis koschevnikovi (Ak) and Apis dorsata(Ad), in a mixed dipterocarp forest at Lambir Hills National Park, Sarawak.

\begin{tabular}{|c|c|c|c|c|c|}
\hline \multirow{2}{*}{$\begin{array}{l}\text { Experiment, } \\
\text { \# and date }\end{array}$} & \multirow{2}{*}{$\begin{array}{c}\text { Time and } \\
\text { site }^{* *}\end{array}$} & \multirow{2}{*}{$\begin{array}{l}\mathrm{N} \text { obs } \\
\text { (level) }\end{array}$} & \multirow[t]{2}{*}{ Hypotheses* } & \multicolumn{2}{|c|}{ New tags } \\
\hline & & & & $\mathrm{Ak}$ & Ad \\
\hline \multicolumn{6}{|l|}{ in 1993} \\
\hline \multirow[t]{2}{*}{ 1,17 Apr } & $0730-1200 \mathrm{~T} 1$ & $1-7$ & $1-3$ & 60 & \\
\hline & $0820-1140 \mathrm{~T} 2$ & 2 & $1-3$ & 121 & \\
\hline \multirow[t]{2}{*}{$2,18 \mathrm{Apr}$} & $0800-1040 \mathrm{~T} 2$ & 4 & $2-4$ & 293 & \\
\hline & $1300-1445 \mathrm{~T} 1$ & 3 & $2-4$ & 460 & \\
\hline \multirow[t]{2}{*}{ 3,19 Apr } & $0815-1530 \mathrm{~T} 1$ & 5 & $2-4$ & 25 & 108 \\
\hline & $0830-1500 \mathrm{~T} 2$ & 5 & $2-4$ & 49 & \\
\hline \multirow[t]{2}{*}{$4,20 \mathrm{Apr}$} & $0700-1045 \mathrm{~T} 1$ & 4 & $2-4$ & & 700 \\
\hline & $0835-1300 \mathrm{~T} 2$ & 7 & $2-4$ & & \\
\hline \multirow[t]{2}{*}{ 5,21 Apr } & $0830-1240 \mathrm{~T} 1$ & 6 & $2-4$ & & \\
\hline & $0710-1130 \mathrm{~T} 2$ & 6 & $2-4$ & & \\
\hline \multirow[t]{2}{*}{ 6, $22 \mathrm{Apr}$} & $0730-1010 \mathrm{~T} 1$ & 3 (low) & $2-4$ & & \\
\hline & $0715-1045 \mathrm{~T} 2$ & 3 (high) & $2-4$ & & \\
\hline \multirow[t]{2}{*}{ 7,23 Apr } & $0655-1150 \mathrm{~T} 1$ & 6 (high) & $2-4$ & & \\
\hline & $0718-1150 \mathrm{~T} 2$ & $6($ low) & $2-4$ & & \\
\hline \multirow[t]{2}{*}{ 8, 24 Apr } & $0648-1338 \mathrm{~T} 1$ & 4 (high) & $2-4$ & 50 & \\
\hline & $0716-1338 \mathrm{~T} 2$ & 4 (high) & $2-4$ & 62 & \\
\hline $9,24 \mathrm{Apr}$ & $1515-1655$ lab & 9 & $2-4$ & & \\
\hline \multirow{2}{*}{$10,25 \mathrm{Apr}$} & 0830-0928 T1 & 2 (low) & $2-4$ & & \\
\hline & 0845-1015 & 2 (low) & $2-4$ & & \\
\hline \multicolumn{6}{|l|}{ in 1995} \\
\hline \multirow[t]{2}{*}{ 11, $20 \mathrm{Mar}$} & $0725-0940$ T2 & 37 & $1-3$ & 415 & \\
\hline & 0957-1348 T1,Ww & $4-5$ & $1-4$ & & \\
\hline \multirow{2}{*}{ 12, $21 \mathrm{Mar}$} & 0640-0845 lab & 4 & 2 & 100 & \\
\hline & $0708-1105 \mathrm{~T} 2$ & 12 (top,mid) & 2,3 & 464 & \\
\hline \multirow[t]{2}{*}{ 13, $22 \mathrm{Mar}$} & 0700-1140 T1,Ww & 7 & $2-4$ & & \\
\hline & $1315-1600 \mathrm{lab}$ & 2 & 3 & 113 & \\
\hline 14, $23 \mathrm{Mar}$ & $0650-1202 \mathrm{~T} 2$ & 9 & 2,3 & 340 & \\
\hline \multirow{2}{*}{ 15, $24 \mathrm{Mar}$} & 0643-0907 T1 & 24 & $1-4$ & 200 & \\
\hline & $1250-1320 \mathrm{lab}$ & 3 & 2 & & \\
\hline $16,25 \mathrm{Mar}$ & 0720-1055 Ww & 3 & 2,3 & & \\
\hline \multirow[t]{3}{*}{ 17, $30 \mathrm{Mar}$} & $0632-0744 \mathrm{~T} 2$ & 11 (top,mid) & $1-3$ & 250 & \\
\hline & $0803-1130 \mathrm{Ww}$ & 6 & $1-3$ & & \\
\hline & $1300-1520$ lab & 2 & 3 & 150 & \\
\hline \multirow[t]{3}{*}{ 18, $31 \mathrm{Mar}$} & $0625-0915 \mathrm{~T} 1$ & 12 & $1-4$ & & \\
\hline & $0924-1050 \mathrm{~T} 2$ & 8 & $1-3$ & & \\
\hline & $1146 \quad \mathrm{ab}$ & 1 & 2 & & \\
\hline \multirow[t]{2}{*}{$19,1 \mathrm{Apr}$} & $0640-1002 \mathrm{~T} 1$ & 19,6 & $2-4$ & & \\
\hline & $0717-1040 \mathrm{Ww}$ & 3 & 2,3 & & \\
\hline $19,1 \mathrm{Apr}$ & $1100-1142 \mathrm{~T} 2$ & 6,9 & 2,3 & & \\
\hline \multirow[t]{3}{*}{$20,2 \mathrm{Apr}$} & $0618-0915$ T3 & 33 & $1-4$ & & \\
\hline & 1030-1049 lab & 5 & 2 & & \\
\hline & & Total no. mar & arked & 3152 & 808 \\
\hline
\end{tabular}

*see text in Methods and Materials.

**T1, T2, T3: Tree tower 1, 2 and 3, respectively, Ww: Walkways between T1 and T2, and lab: the laboratory house.

placed either near the middle of walkways or at the trees between walkways.

In 1993, our experiments tested whether different feeder presentation schedules, in part following nectar secretion patterns noted for tropical trees (Frankie et al., 1976; Frankie and Haber, 1983), affected bee movement patterns. Experiment sequences were as follows: Four 
two-day baiting runs at $\mathrm{T} 1$ and $\mathrm{T} 2$ mimicked flowering trees that 1) produce nectar synchronously, first in the morning, then in the afternoon; 2) produce nectar at different times, one in the morning and one in the afternoon; 3 ) produce nectar simultaneously, but in different strata (high or low, the $32-45 \mathrm{~m}$ levels, or the 3-20 m levels), or 4) produce nectar simultaneously and at the same level, but only at high or low levels. The paired experiments were reciprocal. That is, when asynchronous timing or placement were used, each tower was used once in each configuration. During 1995, studies included observations on bee movement along the walkway, between LHS and T3, and to the superior two platforms of T1, at 45 and $55 \mathrm{~m}$.

Foraging bees at feeders, Apis koschevnikovi $(A k)$ or A. dorsata $(A d)$ were tagged by painting a patch on the thorax or abdomen. Bees continued imbibing while paint was applied. Tag loss due to messy application or smearing by bees attempting to remove paint was minimal. However, an instance of massive recruitment by $A d$ led to stinging of the observer, halting further work on one day. Bees were marked with a different color-white, yellow, green, pink, fluorescent orange, light blue or red - at forage sites. Color corresponded to feeders at a particular height. At T1, bees were marked at $3 \mathrm{~m}, 16 \mathrm{~m}$ and $33 \mathrm{~m}$ above ground level. At T2, bees were marked at $4 \mathrm{~m}, 20 \mathrm{~m}, 32 \mathrm{~m}$ and $45 \mathrm{~m}$. Bees at ground level were also marked at feeders near the laboratory house, which was $620 \mathrm{~m} \mathrm{SE}$ of T2 and $400 \mathrm{~m} \mathrm{SE}$ of T1. For 1993 studies, foragers of $A k$ and $A d$ were tagged at all the indicated levels at T1 and T2, on the thorax or abdomen, respectively. In 1995 no $A d$ were present; $A k$ were tagged at two levels on T2, and at ground level near the laboratory house.

Field data were taken on numbers of marked and unmarked foragers at individual feeding stations by repeated censusing, in which an observer moved among feeders, usually spending the same amount of time at each. Several counts at each feeder during a day were usually made, but census intervals varied, depending on the length of the aerial transect and number of total census counts (Table 1). Foragers were generally tagged in batches of 20 or 100 at a particular level. Unmarked foragers were painted until several hundred were marked (Table $1)$.

\section{RESULTS}

\section{Discovery and Recruitment}

Upon initial bait presentations in 1993 and 1995 at canopy level, feeders were discovered by foraging $A k$ in less than 5 minutes. After four days when no baits had been present, an unmarked $A k$ carrying a small pollen load (no flowers were near the tree-tower) arrived almost instantly at a bait placed at $45 \mathrm{~m}$ at 0635 . Five foragers arrived within $2 \mathrm{~min}$ and departed in less than 15 seconds. The first marked bees, originally from $20 \mathrm{~m}$ and $45 \mathrm{~m}$, arrived within $6 \mathrm{~min}$ of bait presentation. Foragers of $A d$ found feeders after two days of foraging by $A k$, then visited all feeders. Apparently from a single colony, suggested by lack of aggression between foragers, the estimated number of $A d$ matched or exceeded that of $A k$ from multiple colonies (Table 2). Intertree movement of marked foragers, covering 220 meters between $\mathrm{T} 1$ and $\mathrm{T} 2$, occurred in as little as $10 \mathrm{~min}$ for $A k$ and $6 \mathrm{~min}$ for $A d$ (see following section). Once foraging colonies were trained to baits, new baits in different positions were rapidly discovered.

On the final experiment in 1995, baits positioned in T3 before dawn (approximately 0610) attracted bees at $60 \mathrm{~m}$ by 0618 . The first marked bees were spotted on the highest and next highest levels at 0646 . Each marked bee had been marked at $45 \mathrm{~m}$ on T2. Early arrivals flew into the tree upwind, apparently just above the canopy. Later, bees flew back and forth along the tree trunk, while flying upward or downward. The lower two levels of T3 were visited by 
Table 2. Mark-recapture estimates of honeybee forager populations (N: mean, and $95 \%$ of Confidence Limit) at Lambir Hills National Park, Sarawak.

\begin{tabular}{|c|c|c|c|}
\hline Date, species & Observation post & $\mathrm{N}$ & $95 \%$ C. I. \\
\hline \multicolumn{4}{|c|}{ Apis koschevnikovi } \\
\hline 17 Apr '93 & $\mathrm{T} 1$ & 455 & 103 \\
\hline \multirow[t]{2}{*}{18 Apr '93 } & $\mathrm{T} 1$ & 1796 & 265 \\
\hline & $\mathrm{T} 2$ & 1676 & 189 \\
\hline \multirow[t]{2}{*}{19 Apr '93 } & $\mathrm{T} 1$ & 2313 & 300 \\
\hline & $\mathrm{T} 2$ & 2793 & 447 \\
\hline 20 Apr '93 & $\mathrm{T} 2$ & 1701 & 165 \\
\hline \multirow[t]{2}{*}{21 Apr '93 } & $\mathrm{T} 1$ & 2385 & 518 \\
\hline & $\mathrm{T} 2$ & 1523 & 265 \\
\hline \multirow[t]{2}{*}{22 Apr '93 } & $\mathrm{T} 1$ & 3042 & 1261 \\
\hline & $\mathrm{T} 2$ & 1325 & 164 \\
\hline \multirow[t]{2}{*}{23 Apr '93 } & $\mathrm{T} 1$ & 3619 & 1819 \\
\hline & $\mathrm{T} 2$ & 2516 & 814 \\
\hline \multirow{2}{*}{24 Apr '93 } & $\mathrm{T} 1$ & 3668 & 2045 \\
\hline & $\mathrm{T} 2$ & 2439 & 377 \\
\hline \multirow[t]{2}{*}{25 Apr '93 } & $\mathrm{T} 1$ & 3249 & 1333 \\
\hline & $\mathrm{T} 2$ & 1908 & 531 \\
\hline \multirow[t]{6}{*}{20 Mar '95 } & $\mathrm{T} 2$ & 817 & 158 \\
\hline & Ww & 1453 & 439 \\
\hline & $\mathrm{T} 2$ & 1473 & 534 \\
\hline & $\mathrm{Ww}+\mathrm{T} 1$ & 1739 & 632 \\
\hline & $\mathrm{Ww}+\mathrm{T} 1$ & 1858 & 651 \\
\hline & Ww only & 1686 & 703 \\
\hline \multirow[t]{5}{*}{21 Mar '95 } & lab & 211 & 49 \\
\hline & lab & 282 & 84 \\
\hline & $\mathrm{T} 2$ & 2092 & 487 \\
\hline & $\mathrm{T} 2$ & 4226 & 447 \\
\hline & $\mathrm{T} 2$ & 3465 & 225 \\
\hline \multirow[t]{4}{*}{22 Mar '95 } & Ww-from T2 & 11655 & 2325 \\
\hline & Ww-from lab & 1560 & 214 \\
\hline & Ww-T2 top & 4226 & 447 \\
\hline & Ww-T2 mid & 8532 & 26 \\
\hline 23 Mar '95 & $\mathrm{T} 2$ & 6691 & 621 \\
\hline \multirow[t]{3}{*}{24 Mar '95 } & $\mathrm{T} 1$ & 11545 & 870 \\
\hline & $\mathrm{T} 2$ & 6045 & 476 \\
\hline & lab & 630 & 101 \\
\hline \multirow[t]{3}{*}{25 Mar '95 } & Ww-T2 top & 7588 & 1501 \\
\hline & Ww-T2 mid & 6299 & 1438 \\
\hline & Ww-lab & 8682 & 3395 \\
\hline \multirow[t]{2}{*}{30 Mar '95 } & $\mathrm{T} 2$ & 10064 & 1689 \\
\hline & Ww & 9761 & 935 \\
\hline \multirow[t]{3}{*}{31 Mar '95 } & $\mathrm{T} 1$ & 17518 & 2034 \\
\hline & $\mathrm{T} 2$ & 15381 & 2803 \\
\hline & lab & 2678 & 528 \\
\hline \multirow[t]{3}{*}{1 Apr '95 } & $\mathrm{T} 1$ & 33379 & 4830 \\
\hline & $\mathrm{T} 2$ & 10840 & 2440 \\
\hline & Ww & 25597 & 4278 \\
\hline 2 Apr '95 & $\mathrm{lab}$ & 1986 & 450 \\
\hline & $\mathrm{T} 3$ & 45217 & 5907 \\
\hline Apis dorsata & & & \\
\hline 20 Apr '93 & $\mathrm{T} 1$ & 2310 & 283 \\
\hline 20 Apr '93 & $\mathrm{T} 2$ & 3165 & 477 \\
\hline 21 Apr '93 & $\mathrm{T} 1$ & 3871 & 383 \\
\hline & $\mathrm{T} 2$ & 3352 & 288 \\
\hline 22 Apr '93 & $\mathrm{T} 1$ & 4435 & 414 \\
\hline & $\mathrm{T} 2$ & 2648 & 638 \\
\hline 23 Apr '93 & $\mathrm{T} 1$ & 4758 & 308 \\
\hline & $\mathrm{T} 2$ & 2543 & 629 \\
\hline 24 Apr '93 & $\mathrm{T} 1$ & 4238 & 615 \\
\hline & $\mathrm{T} 2$ & 3126 & 474 \\
\hline 25 Apr '93 & $\mathrm{T} 1$ & 1823 & 262 \\
\hline & $\mathrm{T} 2$ & 3234 & 378 \\
\hline
\end{tabular}


Table 3. Within-tree height fidelity, from re-sightings of marked Apis koschevnikovi and Apis dorsata feeding at tree-towers (T1, T2).

\begin{tabular}{|c|c|c|c|c|c|c|c|}
\hline $\begin{array}{l}\text { Date, } \\
\text { species }\end{array}$ & $\begin{array}{l}\text { Level } \\
\text { Re-Sighted }\end{array}$ & $\begin{array}{l}\text { Level } \\
\text { High }\end{array}$ & $\begin{array}{l}\text { Where } \\
\text { Middle }\end{array}$ & $\begin{array}{l}\text { Marked* } \\
\text { Low }\end{array}$ & \multicolumn{2}{|l|}{$\chi^{2}, \mathrm{p}$} & $\begin{array}{l}\text { Avg.** } \\
\text { Fidelity(\%) }\end{array}$ \\
\hline \multicolumn{8}{|c|}{ Apis koscheonikovi } \\
\hline \multirow[t]{2}{*}{18 Apr '93 } & same & 207 & 123 & 90 & & & \\
\hline & different & 10 & 14 & 2 & 1.15, & $0.28^{* *}$ & 94 \\
\hline \multirow{2}{*}{ 20-21 Apr '93 } & same & 127 & 40 & 34 & & & \\
\hline & different & 11 & 9 & 8 & 5.87, & 0.05 & 87 \\
\hline \multirow[t]{2}{*}{ 22-23 Apr '93 } & same & 40 & 10 & 14 & & & \\
\hline & different & 49 & 7 & 32 & 4.8 & 0.09 & 41 \\
\hline \multirow[t]{2}{*}{ 24-25 Apr '93 } & same & 54 & 6 & 9 & & & \\
\hline & different & 8 & 13 & 25 & 41.2 & 0.001 & 58 \\
\hline \multirow[t]{2}{*}{21 Mar '95 } & same & 113 & 195 & & & & \\
\hline & different & & 55 & 35 & 17.0, & 0.0001 & 76 \\
\hline \multirow[t]{2}{*}{23 Mar '95 } & same & 152 & 67 & & & & \\
\hline & different & & 21 & 34 & 18.4, & 0.0001 & 76 \\
\hline \multirow[t]{2}{*}{24 Mar '93 } & same & 185 & 119 & & & & \\
\hline & different & & 25 & 25 & 2.1 & 0.20 & 69 \\
\hline \multirow[t]{2}{*}{30 Mar '93 } & same & 51 & 39 & & & & \\
\hline & different & & 10 & 13 & 1.3, & 0.36 & 79 \\
\hline \multirow[t]{2}{*}{31 Mar '93 } & same & 42 & 24 & & & & \\
\hline & different & & 13 & 11 & 0.66 & 0.57 & 72 \\
\hline \multirow[t]{2}{*}{1 Apr '93 } & same & 27 & 5 & & & & \\
\hline & different & & 18 & 8 & 1.89, & 0.29 & 49 \\
\hline \multirow{3}{*}{$\begin{array}{l}\text { Apis dorsata } \\
\text { 20-21 Apr '93 }\end{array}$} & & & & & & & \\
\hline & same & 294 & 91 & 57 & 31.3 & 0.0001 & 64 \\
\hline & different & 231 & 49 & 5 & & & \\
\hline \multirow[t]{2}{*}{ 22-23 Apr '93 } & same & 201 & 25 & 6 & & & \\
\hline & different & 138 & 25 & 3 & 1.8, & $0.40^{* *}$ & 56 \\
\hline \multirow[t]{2}{*}{ 24-25 Apr '93 } & same & 141 & 14 & - & & & \\
\hline & different & 111 & 23 & 3 & 6.08, & $0.01^{* *}$ & 45 \\
\hline
\end{tabular}

* levels $32 \mathrm{~m}$ and $45 \mathrm{~m}$ on T2 were pooled.

$* * 2 \times 2$ contingency tables were used because of low expected cell counts of $2 \times 3$

tables (low and middle were pooled), average fidelity also pooled low and middle.

$A k$ after approximately 0710 . The first marked bee from ground level arrived at the $60 \mathrm{~m}$ platform of T3 at 0658 , and the first marked bees from the $20 \mathrm{~m}$ platform on T2 at 0656 . Bees of the lab predominated, to which $59 \%$ of the 224 marked bees sighted on T3 belonged. Only $5 \%$ of the bees seen at T3 were marked, approximately one-half to one-third the ratio of marked bees seen on $\mathrm{T} 1, \mathrm{~T} 2$ or the walkway (see below).

Discovery was not rapid for feeders near ground level when bees had been trained only to middle and upper canopy. Two days of feeder placement at $2 \mathrm{~m}$ on four trees of the walkways between $\mathrm{T} 1$ and $\mathrm{T} 2$ produced no $A k$. In 1995, only 44 of 449 total bees (10\%) arriving at feeders near ground $(1.5 \mathrm{~m})$ at $\mathrm{T} 1$ and $\mathrm{T} 2$ had been marked, compared to $16 \%$ of 26,480 bees at feeders on walkways and tree towers. This difference in proportion was significant by a contingency table test of association $\left(\chi^{2}=6.57, p=0.01\right)$, thus suggesting bees marked in the canopy were less likely to encounter feeders near ground level. On 31 March, 1995, high platforms at $45 \mathrm{~m}$ and $55 \mathrm{~m}$ on T1 received 5 of 59 bees (15\%) tagged at ground level at the lab, while only 1 of 100 bees marked at $\mathrm{T} 2$ at $45 \mathrm{~m}$ came to the feeders on the lowest level (see Fig. 2). In contrast, tests of association indicate bees were no more likely to forage along walkways whether they had been previously trained to feeders at ground level or in the canopy $(p=0.6$, Table 3$)$. Walkways had higher representation from bees marked at the lab on 22 March, then relatively few of these, and predominantly bees from $20 \mathrm{~m}$ on T2 during 


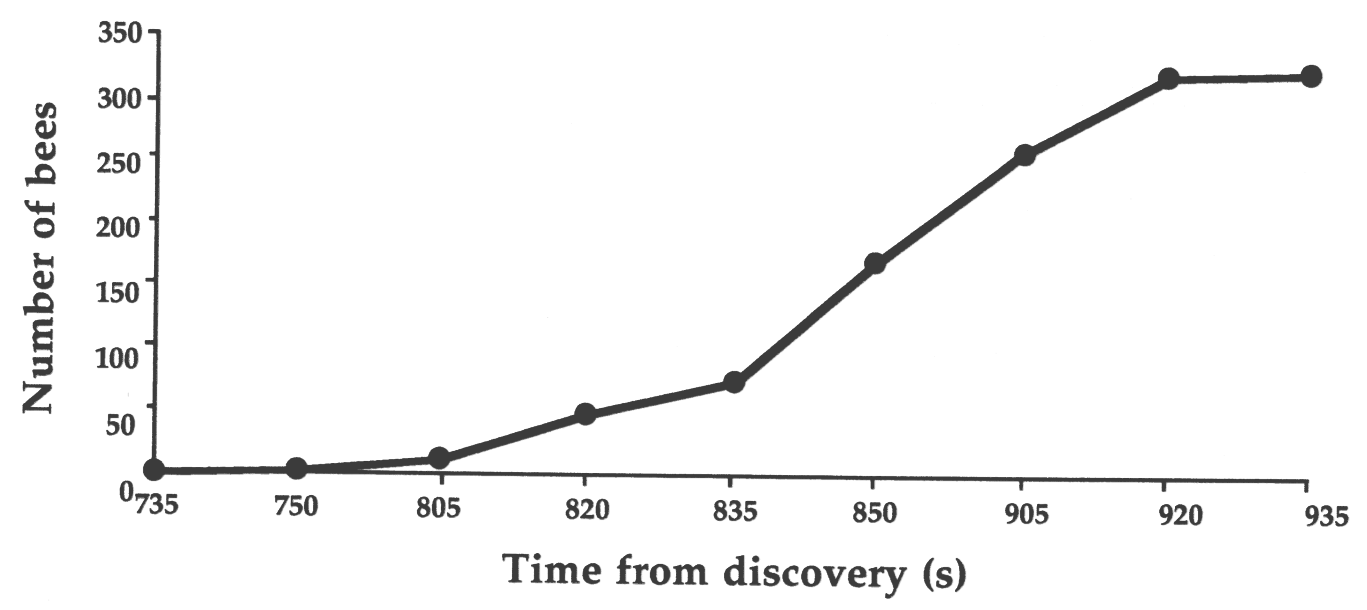

Fig. 1. Logisitic increase in the number of foragers of Apis koschevnikovi on feeders during the first morning of baiting (1995).

March 30 (Table 3).

Recruitment dynamics of $A k$ were followed closely on one occasion after initial feeder discovery on the first day of studies in 1995 (Fig. 1). Their increase on feeders was logistic. The maximum bees found at feeders were 321 , while the total numbers of foragers reached approximately 1-2 thousand (Table 2 ).

\section{Forager Population Size}

At least three colonies of $A k$ foraged at feeders, indicated by departure of bees in different directions after feeding, and by brief skirmishes between foragers in both years, even when baits were not near depletion. Ratios of marked to unmarked foragers allow a single-recapture estimate of forager population size, N, based on the Peterson method (Southwood, 1978, Table 2). Given that tag loss occurred after a few days (foragers were noticeably more often hairless on the thorax a few days after several hundred were painted - paint was likely chewed away by nestmates) we believe the most accurate estimates follow closely the marking of many bees. Estimates therefore did not include several observations after 25 March which would inflate population estimates. The selected data suggest that after two days, recruitment to baits in the canopy involved from roughly 1-12,000 workers of $A k$ in 1995, or an average of 4000 workers bracketed by 95\% confidence intervals (3280-4904) and 1993 (1613-2938, average with $95 \%$ C. I. s). A single colony of $A d$ had forager numbers averaging 3155 (27573552, see Table 2).

\section{Intra-tree movement patterns}

Within tree-towers where bees were marked, $A k$ were slightly more constant to feeders than were $A d$. Notable exceptions occurred in experiments using feeders in only some strata but not others (the 'high-low' and 'high-high', 'low-low' studies of 1993, Table 3, also see Methods). After the aforementioned manipulations in 1993, returns to the same level were seen only in $41 \%$ and $52 \%$ of re-sighted $A k$, similar to the $41-56 \%$ height fidelity among $A d$ at the same time. Although $A d$ also responded with more vagility, changes in movement patterns by $A d$ seemed less affected by the experiments. The average performance of $A k$ was virtually identical in 1993 and 1995, with a mean of $70 \%$ foragers displaying height fidelity. Ad displayed mean height fidelity of $55 \%$.

A grand average of $70 \%(\mathrm{SE}=5.2 \%)$ the 2267 marked $A k$ and $55 \%(\mathrm{SE}=5.5 \%) A d$ 
Table 4. Between-tree height fidelity from re-sightings of marked Apis koschevnikovi and Apis dorsata feeding at tree-towers (T1, T2).

\begin{tabular}{llllcc}
\hline $\begin{array}{l}\text { Date, } \\
\text { species }\end{array}$ & $\begin{array}{l}\text { Level Where } \\
\text { Re-Sighted }\end{array}$ & \multicolumn{2}{l}{$\begin{array}{l}\text { Level Where Marked } \\
\text { High }\end{array}$} & $\begin{array}{c}\chi^{2}, \mathrm{p} \\
\text { Low }\end{array}$ & $\begin{array}{l}\text { Average } \\
\text { Fidelity(\%) }\end{array}$ \\
\hline \multicolumn{2}{c}{ Apis koschernikovi } & & & & \\
24 Mar '95 & Same & 65 & 39 & & \\
& Different & 26 & 43 & $10.9,0.001$ & 59 \\
31 Mar '95 & Same & 88 & 10 & & \\
& Different & 12 & 56 & $87.2,0.0001$ & 52 \\
1993 (total) & Same & 27 & 16 & & \\
& Different & 25 & 12 & $0.2,0.83$ & 55 \\
\hline Apis dorsata & & & & & \\
1993 (total) & Same & 150 & 133 & & 60 \\
& Different & 187 & 47 & $40.9,0.0001$ & 6 \\
\hline
\end{tabular}

observed on tree towers were later sighted at the height they had been marked (Table 3). Of 970 re-sighted $A k$ in 1993, $30 \%$ had changed level, whereas of 1419 re-sighted $A d, 45 \%$ had shifted their foraging stratum (Table 4). Further comparisons were made to determine whether vagility and height fidelity were related to the stratum of marking, given as results of $\chi^{2}$ contingency tests in Table 4. These evaluate movement patterns on 6 days for $A d$ and 13 days for $A k$. Slightly more vagility related to level was found among $A d$ than $A k$. The latter more often tended toward vagility among foragers at lower levels. However, of 13 tests, only 6 showed a significant difference in vagility related to height, and bees marked both at higher and lower levels showed more vagility on one occasion or more for each bee species.

\section{Inter-tree Movement Patterns}

Bees moving between tree-towers appeared less constant in foraging height than did bees foraging within trees. Furthermore, although height fidelity was similar between $\mathrm{Ad}$ (60\%) and $A k$ ( $55 \%$ in both years), vagility related to height differed for these honeybee species (Table 4).

We observed 901 marked bees that moved between towers 1-3 and along canopy walkways. The two most widely separated observations were the laboratory site and the $45 \mathrm{~m}$ platform of T2, $640 \mathrm{~m}$ distant along the ground. A total of 227 marked $A k$ from the lab (ground level) were seen at the uppermost platforms of T1 (see Fig. 2) and T3, while only 2 arrived at the top of T2. In 1993 a total of $24 A k$ marked at the top of T2 or T1 were observed at ground level at the lab. One had been marked at $45 \mathrm{~m}$ less than $2 \mathrm{~h}$ before it was re-sighted at the lab. During the 1995 studies, only 1 forager marked at T2-20 m, was recorded at the lab.

Did bees more often move up or down when flying between tree towers? Tests of association between height at marking and extent of vagility were significant in 3 of 4 cases, covering 8 days for $A k$ and 6 days for $A d$ (Table 4). Bees of upper levels changed height relatively more often among $A d$, and bees of lower levels showed less height fidelity for $A k$. In 1993, daily movements between $\mathrm{T} 1$ and $\mathrm{T} 2$ showed $A k$ had probabilities of changing foraging level that ranged from 0.29 to $1.00(\mathrm{~N}=8$ days, 103 re-sightings) using 4 feeder presentation designs and marked bees from three or four levels on T1 and T2 (see Methods). In 1995 only bees on T2 were marked, and only at two levels, top and mid canopy ( 45 and 20 m). Of 335 re-sighted bees on T1 during this year, during March 24 and March 31 (Fig. 2), 40 $\%$ and $60 \%$, respectively, were at different levels than those at which they were marked. Data taken at individual levels, rather than pooled totals, are appropriate to test whether bees in the 


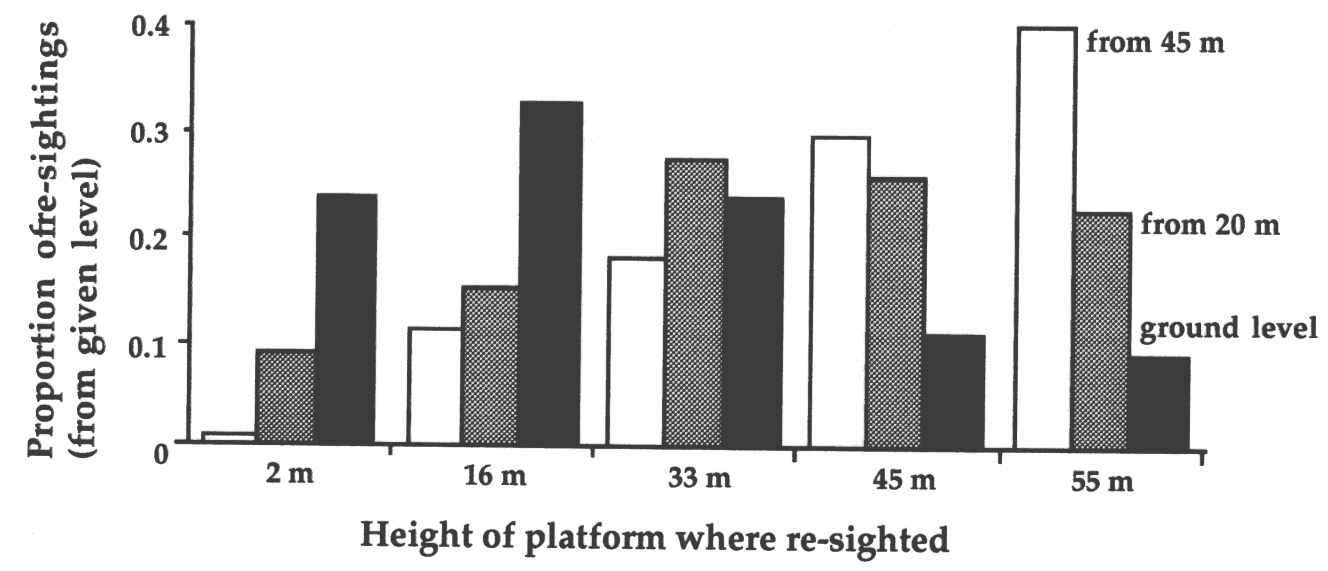

Fig. 2. Height fidelity, expressed as proportions of each height group from bees trained to feeders and marked at T2, then resighted on T1 at platforms of five levels the following day (31 March, 1995). Proportions are standardized transformations that correct for differences among the numbers of individuals marked, and marked individuals re-sighted, at each level.

upper or lower stratum were more likely to change level when moving between trees (Table 4). Both days in 1995 showed significant association between vagility and original level ( $\mathrm{p}<$ 0.001 ), with 51-86\% of $A k$ from $20 \mathrm{~m}$ changing level, compared to $12-29 \%$ of bees from 45 m. In contrast, in $1993 A k$ showed no significant differences, with $48 \%$ of bees marked at 32 to $45 \mathrm{~m}$ changing to lower feeders, and $43 \%$ of bees marked at 3 to $20 \mathrm{~m}$ moving to higher feeders between trees. Among $517 \mathrm{Ad}$ scored for movement between trees, $36 \%$ foraged at the same level where they first were marked, although $55 \%$ were at the same level if upper and lower levels were placed in only two categories, as for $A k$ in 1993. A significant association was found between level and vagility (Table 4), with changes occurring in $79 \%$ of $\mathrm{Ad}$ marked at higher feeders, compared to $26 \%$ among those from lower levels.

Bees arriving at canopy walkways came from all feeders used to mark bees. Walkways between trees were at a similar height to feeders on $\mathrm{T} 1$ at $16 \mathrm{~m}$, with the exception of the first walkway after $\mathrm{T} 2$, at $25 \mathrm{~m}$. On the three days walkways were monitored, three different results were obtained (Table 5). On March 22, bees from the laboratory appeared significantly more often than bees from T2. On 25 March, bees from 20 or $45 \mathrm{~m}$ on T2 were no different in relative frequency from those of the laboratory. On $30 \mathrm{March}$, bees foraging on the walkway were relatively more often those from $\mathrm{T} 2$ at $20 \mathrm{~m}$. In addition, on 22 March the walkway closest to $\mathrm{T} 1$ had the highest proportion of foragers marked at $45 \mathrm{~m}$ on $\mathrm{T} 2$, and walkway 2 had high proportions of foragers from the lab. During other days there was little difference in distribution of foragers from feeding stations among the walkways, although bees from the lab were absent on the four walkways most distant from it (Tables 3, 5).

Table 5. Canopy walkway re-sightings of marked Apis koschevnikovi (1995 only).

\begin{tabular}{|c|c|c|c|c|c|}
\hline \multirow[t]{3}{*}{ Date } & \multirow{3}{*}{$\begin{array}{l}\text { Total Marked } \\
\text { or re-sighted }\end{array}$} & \multicolumn{3}{|c|}{ Level where marked } & \multirow[t]{3}{*}{$\chi^{2}, \mathrm{p}$} \\
\hline & & & & & \\
\hline & & (ground) & $20 \mathrm{~m}$ & $45 \mathrm{~m}$ & \\
\hline \multirow[t]{2}{*}{$22 \mathrm{Mar}$} & re-sighted & 47 & 34 & 68 & \\
\hline & marked & 479 & 300 & 100 & $107,0.0001$ \\
\hline \multirow[t]{2}{*}{$25 \mathrm{Mar}$} & re-sighted & 79 & 60 & 23 & \\
\hline & marked & 879 & 570 & 219 & $0.92,0.63$ \\
\hline \multirow[t]{2}{*}{$30 \mathrm{Mar}$} & re-sighted & 99 & 144 & 5 & \\
\hline & marked & 1029 & 670 & 219 & $58,0.0001$ \\
\hline
\end{tabular}


Table 6. Total numbers of foragers re-sighted on original tree towers and on different tree towers, and estimated proportion of movements between tree towers (T1, T2), in 1993.

\begin{tabular}{|c|c|c|c|}
\hline $\begin{array}{l}\text { Date, } \\
\text { species }\end{array}$ & $\begin{array}{l}\text { Total } \\
\text { re-sighted }\end{array}$ & $\begin{array}{l}\text { Total re-sighted } \\
\text { from other tree }\end{array}$ & $\begin{array}{l}\% \text { movement } \\
\text { between trees }\end{array}$ \\
\hline \multicolumn{4}{|c|}{ Apis koscheonikovi } \\
\hline 18 Apr & 102 & 17 & 17 \\
\hline \multirow[t]{2}{*}{$19 \mathrm{Apr}$} & 120 & 3 & 4 \\
\hline & 89 & 5 & 7 \\
\hline $20 \mathrm{Apr}$ & 149 & 6 & 4 \\
\hline \multirow[t]{2}{*}{$21 \mathrm{Apr}$} & 46 & 1 & 2 \\
\hline & 44 & 2 & 5 \\
\hline \multirow[t]{2}{*}{$22 \mathrm{Apr}$} & 15 & 11 & 73 \\
\hline & 63 & 1 & 2 \\
\hline \multirow[t]{2}{*}{$23 \mathrm{Apr}$} & 11 & 0 & 0 \\
\hline & 22 & 2 & 9 \\
\hline \multirow[t]{2}{*}{$24 \mathrm{Apr}$} & 9 & 0 & 0 \\
\hline & 88 & 0 & 0 \\
\hline \multirow[t]{2}{*}{$25 \mathrm{Apr}$} & 15 & 0 & 0 \\
\hline & 21 & 6 & 29 \\
\hline \multicolumn{4}{|c|}{ Apis dorsata } \\
\hline \multirow[t]{2}{*}{$20 \mathrm{Apr}$} & 129 & 36 & 28 \\
\hline & 133 & 46 & 35 \\
\hline \multirow[t]{2}{*}{$21 \mathrm{Apr}$} & 127 & 58 & 46 \\
\hline & 222 & 1 & $<1$ \\
\hline \multirow[t]{2}{*}{$22 \mathrm{Apr}$} & 74 & 33 & 31 \\
\hline & 130 & 36 & 28 \\
\hline \multirow[t]{2}{*}{$23 \mathrm{Apr}$} & 143 & 20 & 14 \\
\hline & 144 & 44 & 31 \\
\hline \multirow[t]{2}{*}{$24 \mathrm{Apr}$} & 116 & 6 & 5 \\
\hline & 102 & 54 & 53 \\
\hline \multirow[t]{2}{*}{$25 \mathrm{Apr}$} & 46 & 10 & 22 \\
\hline & 145 & 47 & 32 \\
\hline
\end{tabular}

Experiments that varied the timing and position of bait presentation at T1 and T2 during 1993 produced no large changes in inter-tree vagility by bees. To estimate the rate of bee movement between tree towers, the proportion marked at another tower was computed for all the marked bee sightings on individual days, and at each tower (Table 6). Fifty-four resighting were made of $A k$, and 387 of $A d$. For $A k$ the proportions were lower than for $A d$ (grand means: $11 \%, \mathrm{~N}=15 ; 30 \%, \mathrm{~N}=13$, respectively). During the pre-experimental period, vagility ranged from $4 \%$ to $17 \%$ for $A k$, compared to $1 \%$ to $73 \%$ during subsequent days. Rates of inter-tree movement, from re-sightings of marked $A d$, ranged from $28 \%$ to 35 $\%$ before the experiments, and $5 \%$ to $65 \%$ afterward.

\section{Genetic Neighborhood Size}

Bee movement during searching and foraging was rapid within the study area, so that dispersal of viable pollen would presumably occur. The maximum distance a bee traveled between forage sites was about $640 \mathrm{~m}$. Because marked bees foraged over all heights at LHS, their foraging would allow pollen exchange between all plants within an area of at least $640 \mathrm{~m}$ in diameter, which is $0.32 \mathrm{~km}^{2}$.

\section{DISCUSSION}

Bee movement between trees was markedly less influenced by past foraging experience than 
was movement within trees. Height fidelity was greater for both bee species within tree towers, compared to between them. Through varied feeder presentation schedules, movement of Apis koschevnikovi ( $A k$ ) between trees separated by 220 m averaged approximately $11 \%$, while that for Apis dorsata ( $A d)$ was $30 \%$ of re-sighted marked bees. Intratree vagility by $A k$ appeared to increase when feeder presentation was varied. However, we did not obtain clear evidence for more frequent inter-tree movement when our baiting plan mimicked early and late nectar production by trees, or productive flowers in only some strata of those where bees had foraged previously. Notable variation existed in proportions of bees moving between trees during the 6-day experimental period (Table 6). Neither Apis was markedly constant in foraging height, with $70 \%$ intra-tree height fidelity found for $A k$ in both years, compared to $60 \%$ for $A d$. The latter more readily moved downward over the $220 \mathrm{~m}$ between towers, while $A k$ moved upward (see Fig. 2). The probability of changing heights for $A k$ ranged from 0.29 to 1.00 (average 0.58 ) over 6 periods ( 10 days). Probabilities of height shifts were similar and ranged from 0.61 to 0.67 in three study periods and six days for $A d$.

Considering genetic outcrossing, we suggest the ideal distance between individual trees would be that where the probability of a pollinator moving up or down was equal to their probability of moving horizontally. If bees were more inclined to move horizontally, they would skip most flowers of individual trees, and if solely inclined to move vertically, they would not effect outcrossing. The best outcrossing service would be given by foragers that move both up and down trees, and between them. Honeybees were such pollinators. In response to the harvest of one liter of nectar, roughly 3000 bees were mobilized as foragers and potential pollinators, albeit to an artificially compact source of food. In the forest canopy, each searching and foraging bee would visit several dozen to a few hundred flowers after having been recruited to a rewarding nectar source, and thus range over an area of at least a third of a square kilometer. Given these calculations, successful outcrossing seems likely to result from visitation by these honeybees in normal settings, in which one liter of nectar is the standing crop of flowering trees. (A hundred thousand small flowers, each having 10 microliters of nectar, would provide such a resource, see Roubik, 1989, 1993b).

Apis were neither infrequent canopy foragers nor unable to find and then recruit nestmates to feeding sites high in the canopy, among large, emergent trees. Furthermore, in contrast to a few canopy foraging bees or those observed moving between plants (Kevan, 1990; Roubik, 1993a), Apis are not particularly stratum constant. Our quantitative treatment is the first given for individual canopy foragers, thus comparative data are not available for other species.

We expect bees to encounter resources by first searching areas where they previously foraged successfully. As demonstrated for several tropical bees, the acuity of bee memory and performance in three dimensions is formidable (Roubik, 1989). Although we studied honeybees, which have an intranidal system for exchange of information, the mechanism of repeated visits to a species in flower, until its resources are depleted at the patch level, should be the same as that of other bees. For all social bees sharing a nest, memory of forage odor should trigger searching behavior in response to a particular incoming resource. Our initial hypotheses to test were that bees either 'scattered', going in all directions and to any level, or that they were guided, either by landmark shapes, colors, odors, or perhaps merely by gravity (see Kevan, 1990) to seek a resource. Our early hypothesis that bees searched visually or in some other manner for a second tree tower after having found food on the first tower was not supported by results with the canopy walkways or T3, all of which were found within minutes. Bees readily found resources in novel places as well as at all points within the LHS, with the exception of resources at ground level when previous foraging experience was in the canopy. 
In tall tropical forest such as Lambir Hills mixed dipterocarp forest the honeybees foraged from canopy to ground level, but bees were more likely to discover resources in or near the upper canopy or boundary layer. Location of sugar solutions might be aided by more rapid evaporation of liquids and odors in the upper canopy, and location by color would be facilitated in exposed flowers of the canopy. These hypotheses to be tested would help explain the extraordinary ability of honeybees to exploit canopy resources.

ACKNOWLEDGMENTS We express our sincere thanks to Mr. H. S. Lee, Forest Department Sarawak and Prof. K. Ogino, University of Ehime for their kind arrangement of the project in Sarawak. This study was partly supported for one of us (T.I.) by a Japan Ministry of Education, Science and Culture Grant-in-Aid for International Scientific Research (\#04041067).

\section{REFERENCES}

Appanah, S. 1979. The ecology of insect pollination of some tropical rain forest trees. Ph. D. Thesis, University of Malaya, Kuala Lumpur. 213 pp.

- 1981. Pollination in Malaysian primary forests. Malaysian Forester 44: 37-42.

1987. Insect pollination and the diversity of dipterocarps. In: Kostermans, A. J. G. H.

(ed.), Proceedings of the Third Roundtable Conference on Dipterocarps, 277-291.

UNESCO, Jakarta, Java.

. 1990. Plant-pollinator in Malaysian rain forests. In: Bawa, K. S. \& Hadley, M. (eds.), Reproductive Ecology of Tropical Forest Plants, 85-102. Unesco, Paris and The Parthenon Publishing Group, Lancs, U. K.

Bawa, K. S., Bullock, S. H., Perry, D. R., Coville R. E. \& Grayum, M. H. 1985. Reproductive biology of lowland rain forest trees II. Pollination systems. Amer. J. Botany 72:346-356.

Frankie, G. W. \& Haber, W. A. 1983. Why bees move among mass-flowering neotropical trees. In: Jones, C. E. \& Little, R. J. (eds.), Handbook of Experimental Pollination Biology, 360-372. Van Nostrand Reinhold, New York.

, Opler, P. A. \& Bawa, K. S. 1976. Foraging behavior of solitary bees: Implications for outcrossing of a neotropical forest tree species. J. Ecol. 64:1049-1057.

Inoue, T., Salmah, S., Sakagami, S. F., Yamane, S. \& Kato, M. 1990. An analysis of anthophilous insects in central Sumatra; In: Sakagami, S. F., Ohgushi, R. \& Roubik, D. W. (eds.), Natural History of Social Wasps and Bees in Equatorial Sumatra, 175-200. Hokkaido University Press, Sapporo.

\& Hamid, A. A. 1994. Plant Reproductive Systems and Animal Seasonal Dynamics Long-term Study of Dipterocarp Forests in Sarawak. Center for Ecological Research, Kyoto University, Otsu.

, Nakamura, K., Salmah, S. \& Abbas, I. 1993. Population dynamics of animals in unpredictably-changing tropical environments. Journal of Biosciences 18: 425-455.

Kevan, P. G. 1990. How large bees, Bombus and Xylocopa (Apoidea, Hymenoptera) forage on trees: optimality and patterns of movement in temperate and tropical climates. Ethology, Ecology and Evolution 2:233-242.

Murawski, D. A. 1995. Reproductive biology and genetics of tropical trees from a canopy perspective. In: Lowman, M. D. \& Nadkarni, N. M. (eds.), Forest Canopies, 457-493. Academic Press, San Diego, California.

Nagamitsu, T. \& Inoue, T. 1994. Flower-visiting insects collected in lowland dipterocarp forests in Lambir Hills National Park, Sarawak. In: Inoue, T. \& Hamid, A. A. (eds.), Plant 
Reproductive Systems and Animal Seasonal Dynamics - Long-term Study of Dipterocarp Forests in Sarawak, 142-150. Center for Ecological Research, Kyoto University, Otsu.

Nieh, J. \& Roubik, D. W. in press. Food recruitment in a stingless bee, Melipona panamica: communicating location without a scent trail. Behavioral Ecology and Sociobiology.

Roubik, D. W. 1980. Foraging behavior of competing Africanized honey bees and stingless bees. Ecology 61:836-845.

- 1989. Ecology and Natural History of Tropical Bees. Cambridge University Press, Cambridge.

— 1993a. Tropical foragers in the canopy and understory: field data and theory for stratum "preferences". J. Insect Behavior 6: 659-673.

- 1993b. Direct costs of forest reproduction, bee-cycling and the efficiency of pollination modes. J. Bioscience 18: 537-552.

Salmah, S., Inoue, T. \& Sakagami, S. F. 1990. An analysis of apid bee richness (Apidae) in central Sumatra. In: Sakagami, S. F. Ohgushi, R. \& Roubik, D. W. (eds ), Natural History of Social Wasps and Bees in Equatorial Sumatra, 139-174. Hokkaido University Press, Sapporo.

Southwood, T. R. E. 1978. Ecological Methods (2nd edition). Chapman and Hall, London.

Received Aug. 18, 1995

Accepted Oct. 9, 1995

\title{
D. W. ROUBIK, 井上民二, A. A. HAMID 2 種のミツバチによる熱帯雨林の林冠 での採䬲：ミツバチの採䬣高度に対する固執性と樹木の遺伝子交流範囲
}

\begin{abstract}
サラワク州ランビル国立公園内に建設された林冠観測システムを利用して, ミツバチの林冠での 採餌行動を人工給餌器を用いて調査した。給餌器は地上から林冠上部の間のさまざまな高さに設 置し, ミツバチの給餌器間の移動をマーキングによって追跡した。ボルネオミツバチ A pis koscheonikovi とオオミツバチ Apis dorsata の偵察係は約 $220 \mathrm{~m}$ はなれて新たに設置された給餌 器を6分以内に発見し，そこへ，同じ巣に属する運搬係の働きバチ数千頭を 2 日以内に動員した。 同じ木に反復して訪問する場合，同じ高さにやってくる割合は 7 割と高かった。同じ高度に訪問 しない場合，上下ともに訪問が起こった。別の木に新たに訪問する場合には，この割合は 55 か ら $60 \%$ に低下した。同じ高度を再訪問しない場合, オオミツバチは下方向に, ボルネオミツバ チは上方向に訪問がシフトする傾向が強かった。最高 $640 \mathrm{~m}$ 離れた地点でマーキングされた個 体が再捕されており, ミツバチによる遺伝子交流範囲は $0.3 \mathrm{~km}^{2}$ 以上であった。この調査から, 地上から $70 \mathrm{~m}$ 以上に渡って分布する熱帯雨林の林冠内をミツバチは迅速に移動することができ, どの層の花をも利用していることが判明した。
\end{abstract}

